\title{
Вербіиька I.I.
} к.е.н., доцент, доцент кафьедри фбундалентальних та спеціальних дисииплін, Чортківський навчально-науковий інститут підприелниитва $і$ бізнесу Тернопільського національного еконолічного університету

Verbitska Inessa Chortkiv Education and Research Institute of Entrepreneurship and Business Ternopil National Economic University

Гончар Г.П. к.е.н., доиент, доцент кафбедри фбундалентальних та спеціальних дисииплін, Чортківський навчально-науковий інститут підприелнищтва $і$ бізнесу Тернопільського національного економічного університету Honchar Halina Chortkiv Education and Research Institute of Entrepreneurship and Business Ternopil National Economic University

\section{ЗМІСТ ТА ОЗНАКИ МИТНИХ ДЕЛІКТІВ В УКРАЇНІ CONTENT AND SIGNS OF CUSTOMS CRIMES IN UKRAINE}

\begin{abstract}
Анотація. Статтю присвячено аналізу наявних наукових підходів, законодавства України та практики його реалізації задля визначення сутності та особливостей митного делікту, а також відзначено, що проблема відповідальності за порушення митного законодавства сьогодні є досить гострою. Єдиною підставою залучення до відповідальності за митні правопорушення $\epsilon$ наявність складу митного делікту (митного правопорушення). Сукупність порушень митних правил характеризується певними ознаками, які властиві ій саме як цілісному явищу, на відміну від властивостей та ознак окремого правопорушення. Виявлено, що митну деліктність можна охарактеризувати за певними ознаками, а саме за станом, об'єктом, структурою, динамікою та географією. Зазначено, що важливою є боротьба з митними деліктами, які завдають великих збитків та становлять загрозу економіці країни.

Ключові слова: митні правила, митна деліктність, митне правопорушення, адміністративний делікт, митне законодавство.
\end{abstract}

Постановка проблеми. Один 3 найбільш важливих стратегічних напрямів удосконалення діяльності митних органів України сьогодні полягає у виявленні та припиненні економічних злочинів і правопорушень у митній сфері. Розвиток митного законодавства щодо притягнення до адміністративної відповідальності за порушення митних правил сприяє реальній інтеграції нашої держави до Європейського співтовариства.

Розвиток економічної активності населення України, різке посилення міграційних процесів та гуманітарних зв'язків, міжнародного туризму, зокрема його комерційних різновидів, а також розбалансованість економіки, прозорість кордонів, спад виробництва та прогресуюче зростання цін призвели до падіння життєвого рівня населення i, як наслідок, втягнення значної частини громадян у протиправне переміщення товарів через митний кордон України.

Аналіз останніх досліджень і публікацій. Проблематика застосування відповідальності за порушення митних правил та протидії таким правопорушенням широко висвітлена у працях вітчизняних науковців. Теоретичні аспекти порушень митних правил вивчали С. Дьоміна, С. Ківа- 
лов, В. Колпаков, О. Остапенко, П. Пашко, О. Серих. Адміністративно-правовий механізм запобігання порушенням митних правил та протидії ним досліджували такі науковці, як І. Гуцул, О. Константа, М. Кравець, I. Яромій. Однак, не применшуючи значимості наукових досягнень, маємо зазначити, що вивчення економічної літератури з досліджуваної тематики показало, що серед наявних наукових видань $є$ недостатньо напрацювань щодо сутності та особливостей митного делікту.

Виділення не вирішених раніше частин загальної проблеми. Загалом сучасний стан митного законодавства дає змогу виявити специфіку адміністративного примусу й заходів адміністративної відповідальності як його структурного елементу в митній сфері. Правоохоронна функція посідає найважливіше місце в компетенції митних органів, оскільки вони, зокрема, ведуть адміністративне провадження у справах про порушення митних правил. Водночас виникає необхідність розкриття поняття та сутності порушень митних правил.

Мета статті. Головною метою роботи $\epsilon$ дослідження теоретичних та прикладних аспектів митних деліктів в Україні, виокремлення проблемних аспектів функціонування митної політики в Україні.

Виклад основного матеріалу. Термін «митні правила» $є$ узагальненим поняттям, яке включає значне коло термінів, стандартів та правил, що регламентують здійснення особливого виду державної діяльності. Відповідно до митного законодавства за часи незалежності України, порядок переміщення через митний кордон України товарів і транспортних засобів, митне регулювання, пов'язане зі встановленням та справлянням податків і зборів, процедури митного контролю та оформлення, боротьба 3 контрабандою та порушеннями митних правил, спрямовані на реалізацію митної політики України, становлять митну справу [10].

У структурі адміністративних правопорушень митні правопорушення посідають самостійне місце через те, що їх об'єднує загальний об'єкт посягання, а саме суспільні відносини, що виникають у сфері митної справи.
Новий МКУ, який було прийнято у 2012 році, не виправив однієї суттєвої вади попереднього документа. Як і попередній МКУ, новий документ акцентує увагу на тому, що порушення митних правил є адміністративним правопорушенням. Як справедливо відзначає I. Яромій, для всіх порушень митних правил спільним є об'єкт посягань, а саме суспільні відносини, що виникають у галузі державної митної політики та державної митної справи, відповідно до чого, всі порушення митних правил посідають власне місце у загальноприйнятій структурі адміністративних порушень [16].

Загалом науковці по-різному трактують сутність поняття «порушення митних правил». Так, учений-практик Т. Курило під порушенням митних правил розуміє протиправні, винні (навмисні або необережні) дії чи бездіяльність, які посягають на встановлений порядок переміщення через митний кордон України товарів і транспортних засобів, здійснення митного оформлення й митного контролю за ними, обкладання митом, податками та митними зборами товарів i транспортних засобів [9, с. 100].

На думку української дослідниці О. Константи, порушення митних правил - це акт зовні об'єктивованої суспільно шкідливої, протиправної, винної, адміністративно-караної в галузі митної справи вольової поведінки певної фізичної особи, що не перебуває на момент вчинення відповідного діяння у зв'язках служби з митним органом (громадянина, посадової особи підприємства).

Дослідниця підкреслює, що порушення митних правил $\epsilon$ публічно-правовими деліктами, склади яких встановлюються в митному законодавстві для забезпечення організованогофункціонуваннямитнихправовідносин, митного правопорядку, запобігання вчиненню не стільки суспільно небезпечних, скільки таких, які суперечать упорядкованій реалізації митної справи в державі, діянь $[7$, с. 8$]$.

С. Дьоміна поділяє порушення митних правил залежно від того, на яку саме складову частину митної справи посягає те чи інше порушення. Так, дослідниця виокремлює такі дві групи митних правопорушень: 
- порушення митних правил, що посягають на таку складову частину митної справи, як здійснення митного контролю та митного оформлення;

- порушення митних правил, що посягають на таку складову частину митної справи, як нарахування та справляння податків i зборів [4, с. 77].

На думку іншого українського дослідника П. Пашка, склад порушення включає ознаки, що характеризують зовнішній акт поведінки особи, його спрямованість і наслідки, та ознаки, що характеризують самого правопорушника і його психічне ставлення до вчиненого. Відповідно, ознаки складу порушення митних правил об'єднуються в чотири групи (елементи), що характеризують об'єкт порушення митних правил; об'єктивний бік порушення митних правил; суб'єкт порушення митних правил; суб'єктивний бік порушення митних правил [12, с. 450].

Варто зауважити, що між порушенням митних правил та митними злочинами існує суттєва різниця. Так, за справедливим твердженням О. Константи, основною відмінною рисою порушень митних правил від митних злочинів $€$ їх менша суспільна небезпека. Склади як порушень митних правил, так і митних злочинів встановлюються в законодавстві України задля правової охорони одних і тих же суспільних цінностей, благ у галузі митної справи. Інститут порушень митних правил порівняно із засобами кримінального права, на думку дослідниці О. Константи, відіграє «додаткову» роль для досягнення цілей забезпечення митних інтересів держави [7, с. 8-9].

Сукупність порушень митних правил характеризується певними ознаками, які властиві ій саме як цілісному явищу, на відміну від властивостей та ознак окремого правопорушення, тобто митна деліктність характеризується станом, структурою, динамікою та географією.

Варто зазначити, що порушення митних правил є частиною адміністративної деліктності, тому для їх вивчення необхідно використовувати загальнотеоретичні знання про деліктність, знання адміністративної деліктології $[15$, с. 8$]$.
Під деліктністю в юридичній науці розуміють правопорушення, що приводить до вжиття заходів адміністративної відповідальності [2].

Кваліфікація адміністративних деліктів

\begin{tabular}{|l|l|}
\hline \multicolumn{1}{|c|}{ Дослідник } & \multicolumn{1}{|c|}{ Визначення } \\
\hline П. Гагай [1] & $\begin{array}{l}\text { Оцінка юридичного факту, що містить } \\
\text { формальні ознаки адміністративного } \\
\text { делікту, котра полягає у співвідно- } \\
\text { шенні такого діяння та відповідної } \\
\text { норми законодавства про адміністра- } \\
\text { тивні правопорушення, а також у } \\
\text { необхідному юридичному реагуванні, } \\
\text { встановленому законодавством. }\end{array}$ \\
\hline В. Колпаков [6] & $\begin{array}{l}\text { Синонім терміна «адміністративне } \\
\text { правопорушення» або «адміністра- } \\
\text { тивний проступок». }\end{array}$ \\
\hline О. Остапенко [13] & Конкретна протиправна поведінка. \\
\hline
\end{tabular}

Під станом митної деліктності слід розуміти кількість порушень митних правил проступків в абсолютних цифрах або відносних показниках. Митна деліктність може характеризуватися як кількістю осіб, яких притягують до відповідальності за порушення митних правил, так і кількістю виявлених порушень митних правил. Показниками поширеності митної деліктності є іiі рівень (абсолютні числа правопорушень, правопорушників) та інтенсивність (коефіцієнти).

На стан митної деліктності впливають такі зміни в чинному законодавстві, як, наприклад, виключення деяких товарів 3 переліку предмета митного правопорушення, збільшення або зменшення мінімального розміру предмета правопорушення, $з$ якого встановлюється кримінальна відповідальність.

Структурою митної деліктності є якісний показник, який визначає питому вагу, співвідношення всередині цього масиву різних видів порушень митних правил і залежить від вибору критерія побудови. Під час характеристики системи митної деліктності можна виокремити такий показник структури, як склад порушення митних правил (безпосередній об'єкт посягання; ознаки об'єктивної сторони; суб'єкт; форма вини діяння (зокрема, співвідношення умисних і необережних порушень митних правил); спосіб вчинення порушення митних правил тощо). 
Щодо об'єкта посягання, то загальним об'єктом порушень митних правил є встановлений порядок управління. Порушення митних правил об'єднує родовий об'єкт, а саме митна справа. Безпосередніми об'єктами порушень митних правил є митний контроль, митні режими, митне оформлення, порядок справляння митних платежів [5, с. 217].

Якщо характеризувати порушення митних правил за ознакою об'єктивної сторони, то слід зазначити, що більшість порушень митних правил вчиняється у формі активної дії. Проте такі порушення митних правил, як неподання митному органу звітності щодо товарів, які перебувають під митним контролем (ст. 475 Митного кодексу України) [11], недекларування товарів, транспортних засобів комерційного призначення (ст. 472 МКУ), можуть вчинюватися у формі бездіяльності.

Способами вчинення порушень митних правил можуть бути використання спеціально виготовлених сховищ (тайників) та інших засобів або способів, що ускладнюють виявлення таких товарів, або надання одним товарам вигляду інших; подання митному органу як підстави для переміщення товарів підроблених документів чи документів, одержаних незаконним шляхом, або таких, що містять неправдиві відомості щодо найменування товарів, їх ваги (з урахуванням допустимих втрат за належних умов зберігання й транспортування) або кількості, країни походження, відправника та/або одержувача, кількості вантажних місць, їх маркування та номерів, неправдиві відомості, необхідні для визначення коду товару згідно з УКТ ЗЕД та його митної вартості [14, с. 44-45].

Якщо говорити про суб'єктивну сторону порушення митних правил, то склади цих порушень передбачають як умисну форму вини, так і необережність. У структурі митної деліктності можна також виокремити повторну деліктність, деліктність різних соціальних груп населення (підприємців, громадян України, іноземців, чоловіків, жінок), деліктність спеціальних суб'єктів (професійну деліктність) тощо. Наступною ознакою митної деліктності $є$ динаміка митної деліктності. Динаміка митної деліктності - це зміна (збільшення, зменшення) кількісних та якісних показників порушень митних правил загалом за певний період (тиждень, місяць, рік, п’ять років тощо) на тій чи іншій території. При цьому в структурі митної деліктності можна прослідкувати динаміку поширення окремих видів порушень митних правил.

Поширення порушень митних правил та їх окремих видів не є однаковим у різних регіонах, районах, територіальних одиницях. Такий розподіл кількісних та якісних характеристик порушень митних правил та їх видів в територіальному аспекті називається географією.

Географія митної деліктності - це іiї просторово-часовий розподіл. 3 огляду на специфіку митної деліктності більшість порушень митних правил вчинюється у прикордонних областях, але для окремих видів порушень митних правил такий географічний розподіл не $є$ характерним. Наприклад, таке порушення митних правил, як порушення порядку зберігання товарів на митних складах та здійснення операцій із цими товарами (ст. 478 МКУ) [3], вчинюється на митному складі та пов'язане 3 порушенням порядку проведення операцій 3 товарами, що зберігаються в режимі митного складу на митних складах. Порушення порядку або строків розпорядження товарами, розміщеними у магазині безмитної торгівлі, відповідальність за яке встановлена ст. 479 МКУ [11], обмежується територією магазину безмитної торгівлі [14, с. 45-46].

Склад правопорушення $є$ безпосередньою юридичною підставою кваліфікації порушення митних правил та своєрідним інструментом, за допомогою якого встановлюється відповідність між ознаками діяння та деліктної норми.

Будучи юридичною конструкцією та правовим поняттям, склад правопорушення слугує впорядкуванню зіставлення факту та права. При цьому склад порушення митних правил:

- дає змогу визначити коло ознак, які слід зіставляти;

- дає можливість з'ясувати послідовність зіставлення окремих ознак;

- сприяє абстрагуванню від тих ознак, які не мають значення для кваліфікації;

- за відсутності збігу хоча б однієї ознаки дає підстави дійти висновку про відсутність 
цього складу правопорушення та перейти до встановлення наявності іншого складу порушення митних правил;

- за відсутності збігу з ознаками жодної 3 чинних норм МК України є підставою для висновку, що таке діяння не $є$ адміністративно-караним;

- в разі констатації наявності всіх ознак складу правопорушення $є$ підставою для переходу до вирішення інших питань, зокрема призначення покарання, звільнення від покарання.

Адміністративно-правова оцінка (кваліфікація правопорушення) може привести до таких результатів (висновків), як наявне порушення митних правил; діяння, вчинене за обставин, які виключають протиправність вчиненого; діяння, що через малозначність не становить суспільної небезпеки; ознаки злочину у скоєного.

Рішення посадових осіб органів доходів і зборів або судді про кваліфікацію скоєного як порушення митних правил та, відповідно, про необхідність застосування якоїсь статті МК України набуває закріплення у відповідних процесуальних документах, а саме протоколі чи постанові. Кваліфікація, що була закріплена в процесуальних документах, стає обов'язковою та приводить до певних правових наслідків для учасників провадження у справах про порушення митних правил [8, с. 191].

Висновки і пропозиції. Отже, порушення митних правил - це негативне явище для сфери митної справи, вони є найбільш поширеним видом адміністративних правопорушень у сфері зовнішньоекономічної діяльності. На митні органи України покладається широке коло завдань, але чи не основним серед них є запобігання контрабанді та протидія їй, боротьба з порушеннями митних правил, притягнення правопорушників до відповідальності, адже це відіграє значну роль у захисті національних інтересів та гарантуванні економічної безпеки України. Забезпечення захисту цих інтересів потребує відповідних дій з боку держави, тому нині важливою $є$ боротьба 3 митними деліктами, які завдають великих збитків та становлять загрозу економіці країни.

\section{Лimepamypa:}

1. Гагай П. Адміністративно-правова кваліфікація та іiї зв’язок з адміністративним процесом. Форум права. 2009. № 1. C. 99-104.

2. ГончарГ.Теоретичнітаприкладніаспектифіскальнихделіктів. Приазовський економічний вісник. 2019. № 4 (15). URL: http://www.pev.kpu.zp.ua/journals/2019/4_15_uk/41.pdf (дата звернення: 18.08.2020).

3. Гуцул I. Особливості боротьби з митними правопорушеннями в Україні. Економіка. Менеджмент. Підприємниитвво. 2012. № 24 (II). С. 15-21.

4. Дьоміна С. Підходи до систематизації порушень митних правил. Митна справа. 2010. № 3 (69). С. 75-83.

5. Ківалов С. Митна політика та митне право в Україні. Одеса : Юридична література, 2006. 360 с.

6. Колпаков В., Волох О. Функції адміністративно-деліктної законотворчості. Науковий вісник Київського наиіонального університету внутрішніх справ Украӥни. 2007. № 3. C. 42-52.

7. Константа О. Адміністративно-правові заходи боротьби з порушенням митних правил : автореф. дис. ... канд. юрид. наук : спец. 12.00.07 ; ХНУВС. Харків, 2008. 210 с.

8. Кравець М. Кваліфікація порушень митних правил: процесуальний аспект. Право $i$ суспільство. 2014. № 1.2. С. 192-196.

9. Курило Т. Митне право України : навчальний посібник. Львів : Новий світ - 2000, 2007. 240 с.

10. Митний кодекс України : Закон України від 11 липня 2002 року № 92-IV / Верховна Рада України. URL: http://search.ligazakon.ua/1_doc2.nsf/link1/T020092.html (дата звернення: 18.08.2020).

11. Митний кодекс України : Закон України від 13 березня 2012 року № 4495-VI / Верховна Рада України. URL: https://zakon.rada.gov.ua/laws/show/4495-17 (дата звернення: 18.08.2020).

12. Основи митної справи в Україні : підручник / за ред. П. Пашка. Київ : Знання, 2008. 651 с.

13. Остапенко О. Адміністративна деліктологія: соціально-правовий феномен і проблеми розвитку. Львів : ЛІВС при НАВСУ, 1995. 312 с.

14. Серих О. Деліктологічні ознаки порушень митних правил (стан, структура, динаміка, географія). Науковий вісник Міжнародного гуманітарного університету. 2012. № 4. С. 43-47.

15. Серих О. Деліктологія порушень митних правил : автореф. дис. ... канд. юрид. наук : спец. 12.00.07 «Адміністративне право і процес; фінансове право; інформаційне право». Одеса, 2007. 16 с.

16. Яромій I. Адміністративно-правовий механізм запобігання та протидії порушенням митних правил : автореф. дис. ... канд. юрид. наук : спец. 12.00.07. Дніпро, 2018. 20 c.

\section{References:}

1. Hahay P. (2009) Administratyvno-pravova kvalifikatsiya ta yiyi zv'yazok z administratyvnym protsesom [Administrative and legal qualification and its connection with the administrative process]. Forum prava, vol. 1, pp. 99-104.

2. Honchar H. (2019) Teoretychni ta prykladni aspekty fiskal'nykh deliktiv [Theoretical and applied aspects of fiscal delices]. Pryazovs'kyy ekonomichnyy visnyk (electronic journal), vol. 4 (15), pp. 247-252. Available at: http://www.pev.kpu.zp.ua/journals/2019/4_15_uk/41.pdf (accessed 18 August 2020). 
3. Hutsul I. (2012), Osoblyvosti borot'by z mytnymy pravoporushennyamy v Ukrayini. [Features of the fight against customs offenses in Ukraine]. Ekonomika. Menedzhment. Pidpryyemnytstvo, vol. 24 (II), pp. 15-21.

4. Dyomina S. (2010) Pidkhody do systematyzatsiyi porushen' mytnykh pravyl [Approaches to systematization of violations of customs rules]. Mytna sprava, vol. 3 (69), pp. 75-83.

5. Kivalov S. (2006) Mytna polityka ta mytne pravo v Ukrayini [Customs policy and customs law in Ukraine]. Jurid. 1-ra, Odessa, Ukraine (in Ukrainian).

6. Kolpakov V. and Volokh O. (2007) Funktsiyi administratyvno-deliktnoyi zakonotvorchosti [Functions of administrative tort lawmaking]. Naukovyy visnyk Kyyivs'koho natsional'noho universytetu vnutrishnikh sprav Ukrayiny, vol. 3, pp. 42-52.

7. Konstanta O. (2008) Administratyvno-pravovi zakhody borot'by z porushennyam mytnykh pravyl [Administratyvno-pravovi zakhody borot'by z porushennyam mytnykh pravyl] (PhD Thesis), Kharkiv : Nats. yuryd. akad. Ukrayiny im. Ya. Mudroho.

8. Kravets M. (2014) Kvalifikatsiya porushen' mytnykh pravyl: protsesual'nyy aspekt [Qualification of violations of customs rules: procedural aspect]. Pravo i suspil'stvo, vol. 1.2, pp. 192-196.

9. Kyrulo T. (2007) Mytne pravo Ukrayiny [Customs law of Ukraine]. Novyy svit - 2000, Lviv (in Ukrainian).
10. Mytnyy kodeks Ukrayiny, Zakon Ukrayiny vid 11.07.2002 № 92-IV / Verkhovna Rada Ukrayiny. URL: http:// search.ligazakon.ua/1_doc2.nsf/link1/T020092.html (accessed 18 August 2020).

11. Mytnyy kodeks Ukrayiny, Zakon Ukrayiny vid 13.03.2012 № 4495-VI / Verkhovna Rada Ukrayiny. URL: https:// zakon.rada.gov.ua/laws/show/4495-17 (accessed 18 August 2020).

12. Pashko P. (ed) (2008) Osnovy mytnoyi spravy v Ukrayini [Fundamentals of customs in Ukraine] Kyiv : Knowledge (in Ukrainian).

13. Ostapenko O. (1995) Administratyvna deliktolohiya: sotsial'no-pravovyy fenomen i problemy rozvytku [Administrative tort: socio-legal phenomenon and problems of development]. Lviv : LIVS at NAVSU (in Ukrainian).

14. Serukh O. (2012) Deliktolohichni oznaky porushen' mytnykh pravyl (stan, struktura, dynamika, heohrafiya) [Delictological signs of violations of customs rules (state, structure, dynamics, geography)]. Naukovyy visnyk Mizhnarodnoho humanitarnoho universytetu, vol. 4. pp. 43-47.

15. Serukh O. (2007) Deliktolohiya porushen' mytnykh pravyl [Delictology of violations of customs rules] (PhD Thesis), Odessa : Odessa. nat. jurid. acad.

16. Yaromii I. (2018) Administratyvno-pravovyy mekhanizm zapobihannya ta protydiyi porushennyam mytnykh pravyl [Administrative and legal mechanism for preventing and combating violations of customs rules] (PhD Thesis), Dnipro : Dnipropetrovsk State University of Internal Affairs.

Аннотация. Статья посвящена анализу существующих научных подходов, законодательства Украины и практики его реализации с целью определения сущности и особенностей таможенного деликта, а также отмечено, что проблема ответственности за нарушение таможенного законодательства сегодня является достаточно острой. Единственным основанием привлечения к ответственности за таможенные правонарушения является наличие состава таможенного деликта (таможенного правонарушения). Совокупность нарушений таможенных правил характеризуется определенными признаками, которые свойственны ей именно как целостному явлению, в отличие от свойств и признаков отдельного правонарушения. Выявлено, что таможенную деликтность можно охарактеризовать по определенным признакам, а именно по состоянию объекта, структуре, динамике и географии. Указано, что важной является борьба с таможенными деликтами, которые наносят большой ущерб и представляют угрозу экономике страны.

Ключевые слова: таможенные правила, таможенная деликтность, таможенное правонарушение, административный деликт, таможенное законодательство.

Summary. The article performs a comprehensive study of theoretical and applied aspects of customs violations in Ukraine. An analysis of existing scientific approaches, legislation of Ukraine and the practice of was performed in order to determine the nature and features of customs violations and noted that the problem of liability for violation of customs legislation today is quite acute. The only basis for prosecution for customs offenses is the existence of a customs violations (or customs offense). The set of violations of customs rules is characterized by certain features that are inherent in it as a holistic phenomenon, in contrast to the properties and characteristics of a particular offense. It was found that customs delinquency can be characterized by certain features, namely: condition, object, structure, dynamics and geography. It is noted that it is important to combat customs violations, which cause great damage and pose a threat to the country's economy. That is why the fight against fiscal violations and their prevention is an important component of Ukraine's economic security. The process of causality of violations of customs rules means the interaction of the social environment and the person in certain conditions. As a result of such interaction, a new state is formed, which includes customs delinquency - a set of violations of customs rules. The article is made using both general and special methods and techniques, in particular: theoretical generalization, scientific abstraction, methods of induction and deduction, historical method - to determine the economic essence of customs torts. The article stipulates that the object of customs violations (violation of customs rules) is those public relations to which the act is directed and which are harmed as a result of the offense. Thus, it was found that the customs policy plays a significant role in protecting the national interests and guaranteeing the economic security of Ukraine and, accordingly, ensuring the protection of these interests requires appropriate action by the state. That is why it is important now to fight customs violations, which cause great damage and pose a threat to the country's economy.

Keywords: customs rules, customs violations, customs offense, administrative violations, customs legislation. 